\section{Education for a sustainable agriculture}

I very much enjoyed Volume 4, Nos. 3 and 4, of the $\boldsymbol{A} \boldsymbol{J} \boldsymbol{A} \boldsymbol{A}$. Under "Opinion" Dr. Charles A. Francis suggests ten ways to sustain agriculture and development. All ten of his suggestions are important and would help to achieve the sustainable agriculture and development that we seek. Rather than add an eleventh, ten seems so round, I would expand his third suggestion to include a larger concern for our general approach to farmer education for sustainable agriculture and development. Dr. Francis' third suggestion, "Evolve from 'product use' to 'problem solving process' mentality," is crucial. This suggestion involves several issues that require being dealt with and resolved before education for sustainable agriculture and development can take place.

Farmers are not targets. We often talk of those we work with as target audiences. What do we target them for? Education? What kind of education is shot at a target? "Product use" "rea" tion. "Product use" education is not concerned only with information about brand name materials, it also includes the kind of education or information we at land grants are apt to provide. This "product use" education is characterized by short-term answers developed from a process controlled by the land grant system and targeted at farmers. A result of "product use" education is the increased dependency of the target on the provider of education for continued support. "What herbicide can I spray to kill the weeds?" is an example of the dependency created by our traditional approach to education for farmers. We need to correct that approach to that which would break any dependency relationship. Sustainable agriculture and development is carried out by independent empowered farmers.
Time horizon. We often treat education for farmers as if it has to be done today. We shy away from processes that might take a year or two. "Problem solving" education takes time, is not accomplished by one workshop or farm visit, and provides a format for all additional education. Providing a direct answer to a question such as "What herbicide can I spray to kill the weeds?" evades responsible education. Working with the farmer to discover the kinds and numbers of weeds existing in his/her field during various stages of crop growth and their interactions with the crop takes longer, but the farmer begins to discover a method for analysis and decision making that carries over into all aspects of his/her farm operation.

Who is in control of education? When farmers can discover and learn on their own, what will be the function of Extension? This is a question that lurks in the dark regions of our minds, but we hesitate to articulate it, much less answer it. Education for sustainable agriculture and development means education that will empower farmers to be field experts in sustainable agriculture and decision making. Extension and research have an inexhaustible role in working with farmers to achieve that goal.

Learners as teachers. Education for sustainable agriculture and development requires an approach that considers learners as teachers and teachers as learners. We all have something to contribute to the educational process, both as learners and as teachers. Sustainable education involves all participants in both roles. An indirect benefit of such an approach is that processes are developed that encourage "learners as teachers," and these processes will be used by learners when they are asked by neighbors to teach them about sustainable agriculture.

Learning materials as found materials. Education for sustainable agricul- ture and development does not need to rely on centrally produced learning materials. What happens with a crop in the field is the focus of sustainable education. This can be learned best in the field, not in the classroom. Slides, movies, television, and written materials are all substitutes for firsthand field experience. Farmers have this, and working with them in their fields helps them to better see the relationships that exist in their fields. Classroom materials are a substitute that creates a dependency relationship--learners and teachers come to believe that education can take place only with the help of learning materials. Learning materials should be recognized as substitutes for experience and be given their proper role of supporting education, not leading education.

Farmers as researchers. Farmers can and should conduct their own research. Extension should be preparec to help farmers figure out how to conduct this research and then help farmers communicate their research to each other. University researchers have their role in discovering new knowledge. Farmers, too, have a role in discovering what is going on in their fields and developing solutions to help them manage their fields and farms.

The above are a few quick thoughts concerning "sustainable" education. We, too, often neglect thinking about educational processes as we set out to work with farmers. The educational process we use determines the results we will achieve. If sustainable agriculture and development are our goal, then let us use those educational processes that will contribute to that goal.

John Pontius

Extension Specialist

Agriculture

University of Massachusetts

Department of Resource

Economics, Draper Hall

Amherst, MA 01003 
OPINION--Continued from page 98

that it can be applied as needed. NCWC can capitalize on favorable conditions to reduce costs, work, and management. For example, if rainfall is delayed after planting, conditions have permitted me to complete effective weed control with one rotary hoeing and one cultivation. In contrast, CWC systems are committed to the cost of herbicide before post-planting conditions are known. CWC has no flexibility to capitalize on cost-saving opportunities.

Crusting is one problem after planting. For CWC systems, breaking a crust with a rotary hoe is a wholly additional cost. For NCWC systems, the crust-breaking tillage can be an additional benefit of the first scheduled rotary hoeing, so that its cost can be disregarded.

Another threat is early crop failure from many causes: heavy rain, hail, lost weed control, or plant diseases. Crop failure may create two problems peculiar to CWC. The first is the inflexibility of herbicides discussed above. For NCWC, crop failure means that some weed control costs can be avoided. The other potential problem after crop failure is herbicide incompatibility between the lost crop and the replacement crop. Suppose that a field of milo is destroyed by hail on approximately June 15. The most obvious planting option available would be soybeans. There is a good possibility that soybeans would be incompatible with the milo herbicide. Even if the damaged crop is replaced with the same crop, it is difficult to determine whether enough of the original herbicide remains or whether a second application would be too much.

Two additional notorious problems of $\mathrm{CWC}$ are herbicide drift and weed resistance to herbicides. Herbicide drift can damage the applicator's other crops as well as those of neighbors. NCWC has no potential to harm other crops. The fast developing problem of weed resistance to herbicides continues to include more kinds of weeds and expand to more areas of the United States, another problem unique to CWC systems.

Conclusion

CWC generates problems at every stage of the growing season. Problems peculiar to this system include crop rotation restrictions, greater machinery costs, possibly extra pre-plant tillage, a small margin for error in application, herbicidestressed crops, application demands at the busy planting time, inflexibility in coping with various crop conditions after planting, herbicide drift, and weed resistance to herbicides.

NCWC is beset with its own significant challenges. Concerns include informed diversified crop rotation, lengthened planting dates to coordinate the workload of mechanical weed control, and meticulous timing and application of mechanical weed control. Further, extremely wet growing seasons challenge NCWC and reduce the farmer's options. It is important to note, however, that these special concerns are surmounted by learning new skills and better management, not by additional capital outlays.

It is not clear how to tally which system "wins" this competition. I have described how chemical weed control--advertised as convenient in making weed control easier--causes numerous complications, inefficiencies, and unresolvable problems, which do not plague chemical free weed control approaches with row crops.

\section{UPCOMING EVENTS}

March 11-14. International Conference on Agriculture and the Environment at Columbus, Ohio. Organized by The Ohio State University. Environmental, ecological, economic, and social issues are focus. For more information, call (614) 292-8209.

March 15-17. Food safety and pesticide poisoning are key topics at the Pesticide Forum, a 10th anniversary event sponsored by the National Coalition Against the Misuse of Pesticides (NCAMP). Information is available from NCAMP at 701 E Street, SE, Washington, DC 20004, 543-5450.

March 18-20. Farming for the Future: In-Service Training in Organic and Sustainable Agriculture, to be held on the Cornell University Campus, Ith- aca, New York. Sponsored by the Northeast Organic and Sustainable Farmers Network. Open to extension, USDA, and other agriculture professionals. For registration information, contact Judy Green, Cornell Farming Alternatives Program, (607) 255-9832.

March 21-22. A symposium on Prospects for Lupins in North America. Ramada Hotel, St. Paul, Minnesota. Sponsored by Minnesota Extension Service. For information, call Extension Special Programs at (800) 367-5363 or (612) 625-2722.

April 9-11. Use of Cover Crops for Erosion Control is focus of a Soil and Water Conservation Society Spring Conference at Jackson, Tennessee. Contact the Society at 7515 Northeast Ankeny Road, Ankeny, IA 50021,
(515) 289-2331.

\section{LETTERS TO THE EDITOR INVITED}

The AJAA welcomes letters, short or long, commenting on articles in this journal or sharing ideas likely to be of interest to other AJAA readers. Since our space is limited, we do reserve the right not to publish all letters or, at times, to publish only excerpts from them. To take part in this exchange of ideas, write to: Editor, AJAA, $9200 \mathrm{Ed}$ monston Road, Suite 117, Greenbelt, MD 20770. 